some felt diminished by their experience. Over half of all parents interviewed, despite their sad experience, believed that their own personalities had been affected for the good, citing, for example, an increase in patience and a recognition that people matter more than things. More of those who had cared for their baby considered that they had experienced personal growth and that the baby's short life had enriched a wide circle of relationships, both personal and professional. This brought these parents unanimously to agree that home care was the better option.

Medical staff may still react by saying that it is kinder to keep parents uninvolved and for disabled babies to die quickly and quietly. This is treating parents like children, ignoring the baby's personal needs, and also now denying the evidence. Parents need to be encouraged in their parenting, which includes being helped to see things from the child's point of view. As they come to terms with the problems they need more support than has sometimes been given them in the past. ${ }^{6}$ Some personal stories accentuated the need for special help for fathers and siblings in a bereaved family ${ }^{78}$ Hospital and community staff need to learn counselling skills as well as technical competence. This may mean that they need to be counselled themselves, starting with the reminder that parents may find it better to have loved and lost a baby than never to have been close to the child at all. The interviewer was repeatedly told how helpful her visit would have been had it taken place years earlier.

We are grateful for a grant from the Association for Spina Bifida and Hydrocephalus, without which this survey could not have been undertaken. We also thank Drs Stephen Richardson and Anne Griffiths for collecting basic data, Iris Roscoe for retyping the manuscript. Most of all we thank all the parents who shared such moving personal stories with us and thereby taught us how to improve the service for handicapped babies.

A fuller account of this survey including details of the questionnaire, the interviewer's methods, and a more detailed discussion of the conclusions is available from the Association for Spina Bifida and Hydrocephalus.

1 Richardson SA, Goodall J. Trends in the management of spina bifida babies, 1971-81: home care for the non-surgical group. Maternal and Child Health 1984;9:252-7.

2 Lorber J. Results of treatment of myelomeningocoele. An analysis of 524 unselected cases with special reference to possible selection for treatment. unselected cases with special reference

3 Solnit AJ, Stark MH. Mourning and the birth of a defective child. Psychoanal Study Child 1961;16:523-37.

4 Standish L. The loss of a baby. Lancet 1982; ;:611-2.

Saunders C, ed. The management of terminal disease. London: Edward Arnold, 1984.

6 Drotar D, Baskiewicz A, Irvin N, Kennell J, Klaus M. The adaptation of parents to the birth of an infant with a congenital malformation: a hypothetical model. Pediatrics 1975;56:710-7.

7 Pincus L. Death and the family: the importance of mourning. London: Faber and Faber, 1976.

8 Pettle MSA, Lansdowne RG. Adjustment to the death of a sibling. Arch Dis Child 1986;61:278-83.

(Accepted 8 August 1988)

\author{
K R Fogelman, O Manor
}

\begin{abstract}
Follow up analyses of data on the 1958 cohort from the national child development study have shown that the association of smoking in pregnancy with physical and intellectual development diverges between the sexes at age 16, no longer being significantly associated with height in girls. These studies, however, have emphasised that the differences in outcome are small and may be explained by other factors. The analyses have taken account of birth weight and have therefore examined the effects of smoking on subsequent development in addition to this variable. To assess the importance of smoking on development in early adult life and whether the effect is independent of birth weight data from the 1958 cohort at age 23 were analysed. Only weak evidence for a relation between smoking in pregnancy and self reported height of the offspring was apparent once social class, size of family, mothers' height, and birth weight for gestational age were taken into account. After omission of birth weight from the analyses, however, the average difference in height between subjects whose mothers smoked 20 cigarettes a day or more during the second half of pregnancy and those whose mothers did not was 0.93 $\mathrm{cm}$ in men and $1.83 \mathrm{~cm}$ in women. A strong association was also evident with the highest qualification achieved by subjects at this age, suggesting a long term relation between smoking in pregnancy and the intellectual development of the offspring.
\end{abstract}

\section{Introduction}

A causal relation between smoking in pregnancy and the survival and birth weight of the baby is generally accepted. Most of the evidence has come from national cohort studies, in particular the national child development study, of people born in $1958^{12}$ and the 1970 cohort study, the child health and education study. ${ }^{3}$ Early analyses of data from the national child development study, for example, showed that smoking 10 cigarettes a day or more in the second half of pregnancy increased the perinatal mortality rate by $28 \%$ and reduced birth weight by a mean of $170 \mathrm{~g}$ compared with no smoking ${ }^{4}$ and that these results were not changed when possible mediating factors such as social class, maternal age, and parity were allowed for. ${ }^{5}$ Similar results have been reported for the cohort born 12 years later. ${ }^{6}$

Subsequently, a series of follow up studies have examined the development of the children in the national child development study whose mothers had smoked during pregnancy. Smoking was significantly related to the children's height and their attainments in reading and mathematics at the ages of 7 and $11 .{ }^{178} \mathrm{By}$ contrast with the perinatal findings, however, these relations were reduced when possible mediating factors were taken into account, although they were still significant. At age 16 similar results were obtained for attainments in reading and mathematics, but the association of smoking with height in girls had decreased and was no longer significant. ${ }^{9}$ In boys the mean difference in height between the children of nonsmoking mothers and mothers who had smoked 10 cigarettes a day or more $(0.88 \mathrm{~cm})$ was close to the comparable contrast at age 11 . The difference between the sexes was compatible with an association between the mothers' smoking and the rate of the children's growth or their growth to puberty but not between smoking and their eventual adult height (which is achieved by almost all girls by the age of 16). These findings, however, mainly emphasised that 
the differences in outcomes related to smoking in pregnancy were small and that they might be explained by other, unidentified mediating factors.

As a subsequent stage of the study has been completed, when the cohort reached the age of 23 , these relations can be examined further. In particular, the men have reached their adult height. If the hypothesis above is correct the height in each sex should not be different when the mediating factors are taken into account. The children's birth weight for gestational age is a mediating factor that has been taken into account in the previous analyses, which is justifiable if investigating whether smoking in pregnancy affects physical and intellectual development in addition to its effect on birth weight. On the other hand, of at least equal interest is whether smoking in pregnancy affects development even if this is no greater than would be predicted from the relation with birth weight. In other words, are babies who had a lower birth weight associated with their mother's smoking shorter or do they have poorer educational attainment in early adulthood? Or do the differences that existed at birth, as shown by birth weight, disappear by early adulthood?

We performed two sets of analyses to assess the association between smoking in pregnancy and outcomes in terms of physical and intellectual development at age 23 . The first analysis updated those carried out at earlier ages of the cohort and took into account the same potential mediating factors. The second was based on the same variables but excluded birth weight.

\section{Subjects and methods}

We analysed data collected for the national child development study, a longitudinal study of all the people in Britain born in the week 3-9 March 1958. Originally studied at birth by the National Birthday Trust Fund, ${ }^{10}$ members of this cohort have been followed up at the ages of $7,{ }^{1} 11,16,{ }^{2}$ and $23,{ }^{11}$ and a fifth follow up is planned for their early $30 \mathrm{~s} .{ }^{12}$

At birth information on the subjects was obtained from the medical records and an interview with the mother and at school age by parental interviews, medical examinations, personal questionnaires, school questionnaires, and tests of educational attainment. During the follow up study at age 23 the subjects were interviewed by professional interviewers. Of the dependent variables, height was self reported in the course of the interview, and the highest qualification obtained by age 23 was based on the answers to questions about qualifications obtained during education and training, which were grouped on a 16 point scale (no qualifications $=16$; higher degree $=1$ ). ${ }^{13}$ The independent variables were the same as those in the earlier analyses and were selected on the grounds of their relations with growth and educational attainment. ${ }^{23}$ The mother's smoking after the fourth month of pregnancy was recorded as number of cigarettes smoked/day $(0,1-9,10-19, \geqslant 20)$. Social class based on the father's occupation at the time of the subject's birth was reported as professional and intermediate, skilled non-manual, skilled manual, semiskilled or unskilled manual, or no male head of household. The size of the family was the number of children aged under 21 in the household when the subject was 11 and was given as 1 or 2,3 or 4 , and $\geqslant 5$. Birth weight for gestational age was calculated as centiles of the total distribution and entered as a continuous variable. The mother's height, which was self reported at the perinatal interview, was entered as a continuous variable.

The sample population that we analysed, about 8200 people, represents just over half of the known survivors from the original birth cohort and about two thirds of those who were successfully interviewed at the 23 year follow up. The reduced sample results from the requirement to have all the data in a particular analysis and is due to subjects refusing to participate, failure to trace some subjects, and availability of partial information.

General analyses of patterns of response within the study are reassuring but show a slight tendency for the responding sample to be more middle class and to underrepresent certain disadvantaged groups..$^{14}$ A more serious bias is an underrepresentation of ethnic minorities. Repeating the earlier general analyses and omitting later non-respondents does not affect the underlying relations. ${ }^{14}$ More specific checks of the characteristics of the subjects included in our analyses showed that they were similar to those of the original birth cohort. For example, of the analysis sample, $67 \cdot 8 \%$ had mothers who had not smoked during their pregnancy compared with $66.5 \%$ of the full cohort, and $18.7 \%$ had fathers in professional and intermediate occupations and $20.1 \%$ in semiskilled or unskilled occupations, compared with $17 \cdot 0 \%$ and $21 \cdot 3 \%$, respectively, in the original cohort. A more troubling comparison is that between the proportions of subjects born into families with no male head $(1.8 \% v 3.0 \%)$, but the small size of this group makes it improbable that our conclusions would be affected.

\section{STATISTICAL METHODS}

As in the earlier analyses, we used analysis of covariance. Two dependent variables, height and the highest qualification obtained by the age of 23 , were investigated. There were three other important differences from the earlier analyses. Firstly, additional analyses were carried out to assess the effect of omitting birth weight for gestational age from the independent variables. Secondly, the mothers' age did not prove to be related to either of the two outcomes and so was excluded from the multivariate analyses. Thirdly, an extra category was added to the variable that described smoking in pregnancy, so that heavier smokers (smoking $\geqslant 20$ cigarettes/day) could be identified.

Two way interactions were tested in these analyses. None was significant in relation to height, so only the main effects were fitted in these analyses. Two way interactions were included in the analyses of highest qualifications, but only the interaction between social class and size of the family was significant. Separate analyses were carried out for each sex. The highest qualification variable, as expected from the structure of the examinations system, showed some deviation from normality. Although the $F$ test in an analysis of covariance is robust with respect to the assumption of normality, ${ }^{16}{ }^{17}$ we repeated these analyses with several transformations of this variable, and in each case the results were similar to those reported below. In addition to the overall $F$ test the presence of linear and quadratic trends across the categories of smoking were tested for

\section{Results}

Table I shows the results of the analysis of maternal smoking and the height of the offspring at 23 years. The difference between any pair of deviations represents the mean difference in height between those two categories of smoking. The unadjusted difference in the average height of the men whose mothers had not smoked and those whose mothers smoked 20 cigarettes a day or more was $1.42 \mathrm{~cm}$. Adjustment for all of the independent variables reduced the difference to less than $0.5 \mathrm{~cm}$, which is not significant. When birth weight was omitted from the analysis the adjusted difference was $0.93 \mathrm{~cm}$, which borders on significance. 
In women the comparable differences in height were larger, the unadjusted value being $2.53 \mathrm{~cm}$ and the adjusted values being $1.57 \mathrm{~cm}$ and $1.83 \mathrm{~cm}$ respectively. This may seem surprising, given that at age 16 the height of the boys showed the stronger relation with smoking in pregnancy. At age 23 , however, the main difference in the full model was between the women whose mothers had smoked 20 cigarettes a day or more and the remaining women. This group was small and was not examined separately at age 16 . Given also the borderline significance, at a level $(5 \%)$ that is not demanding for a sample of this size, the evidence for a relation between smoking in pregnancy and subsequent adult height when birth weight was taken into account seems to be weak. When birth weight was not included in the analyses the remaining association between smoking in pregnancy and adult height was stronger, especially for women.

Table II shows the results for smoking in pregnancy and the highest qualification obtained by age 23 . The figures are more difficult to interpret, but, broadly, a difference of one point around the overall mean represents the difference between having 1-4 ordinary level (in Scotland ordinary grade) passes at grades A-C

TABLE I-Cigarettes smoked by mother in second half of pregnancy and height of offspring at age 23

\begin{tabular}{|c|c|c|c|c|c|}
\hline & \multirow[b]{2}{*}{$\begin{array}{c}\text { No of } \\
\text { mothers }\end{array}$} & \multirow[b]{2}{*}{$\begin{array}{c}\text { Overall } \\
\text { mean }(\mathrm{SD}) \\
\text { height }(\mathrm{cm})\end{array}$} & \multicolumn{3}{|c|}{ Deviation from overall mean $(\mathrm{cm})^{\star}$} \\
\hline & & & Unadjusted & $\underset{\text { (full model) } \dagger}{\text { Adjusted }}$ & $\begin{array}{l}\text { Adjusted (full } \\
\text { model excluding } \\
\text { birth weight) }\end{array}$ \\
\hline & & Men & & & \\
\hline $\begin{array}{l}\text { No of cigarettes smoked } \\
\text { None } \\
1-9 \\
10-19 \\
\geqslant 20\end{array}$ & $\begin{array}{l}2^{4094} \\
2777^{703} \\
539 \\
75\end{array}$ & $177 \cdot 5(6.96)$ & $\begin{array}{r}0 \cdot 27 \\
-0 \cdot 66 \\
-0 \cdot 37 \\
-1 \cdot 15\end{array}$ & $\begin{array}{r}0.07 \\
-0.20 \\
-0.06 \\
-0.41\end{array}$ & $\begin{array}{r}0 \cdot 17 \\
-0 \cdot 38 \\
-0 \cdot 26 \\
-0.76\end{array}$ \\
\hline $\begin{array}{l}\text { p Value for: } \\
\text { Effect of smoking } \\
\text { Linear trend } \\
\text { Quadratic trend }\end{array}$ & & & $\begin{array}{l}>0.05 \\
>0.05\end{array}$ & $\begin{array}{l}>0.05 \\
>0.05 \\
>0.05\end{array}$ & $\begin{array}{r}0.05 \\
>0.05 \\
>0.05\end{array}$ \\
\hline & & Women & & & \\
\hline $\begin{array}{l}\text { No of cigarettes smoked } \\
\text { None } \\
1-9 \\
10-19 \\
\geqslant 20\end{array}$ & $\begin{array}{l}2821 \\
756 \\
506 \\
79\end{array}$ & $162 \cdot 5(6 \cdot 62)$ & $\begin{array}{r}0.35 \\
-0 \cdot 50 \\
-0.88 \\
-2 \cdot 18\end{array}$ & $\begin{array}{r}0 \cdot 08 \\
0 \cdot 10 \\
-0 \cdot 34 \\
-1 \cdot 49\end{array}$ & $\begin{array}{r}0.20 \\
0.04 \\
-0.76 \\
-1.63\end{array}$ \\
\hline $\begin{array}{l}\text { p Value for: } \\
\text { Effect of smoking } \\
\text { Linear trend } \\
\text { Quadratic trend }\end{array}$ & & & $\begin{array}{l}>0.001 \\
>0.05\end{array}$ & $\begin{array}{l}<0.05 \\
<0.01 \\
>0.05\end{array}$ & $\begin{array}{l}<0.001 \\
<0.001 \\
>0.05\end{array}$ \\
\hline
\end{tabular}

For each category of smoking.

†Social class, size of family, birth weight for gestational age, and height of mother.

TABLE II -Cigarettes smoked by mother in second half of pregnancy and highest qualification obtained by offspring at age 23

\begin{tabular}{|c|c|c|c|c|c|}
\hline & \multirow[b]{2}{*}{$\begin{array}{c}\text { No of } \\
\text { mothers }\end{array}$} & \multirow[b]{2}{*}{$\begin{array}{c}\text { Overall } \\
\text { mean }(\mathrm{SD}) \\
\text { grade of } \\
\text { qualification }\end{array}$} & \multicolumn{3}{|c|}{ Deviation from overall mean } \\
\hline & & & Unadjusted & $\begin{array}{c}\text { Adjusted } \\
\text { (full model) }\end{array}$ & $\begin{array}{l}\text { Adjusted (full } \\
\text { model excluding } \\
\text { birth weight) }\end{array}$ \\
\hline \multicolumn{6}{|c|}{ Men } \\
\hline $\begin{array}{l}\text { No of cigarettes smoked } \\
\text { None } \\
1-9 \\
10-19 \\
\geqslant 20\end{array}$ & $\begin{array}{l}2802 \\
707 \\
542 \\
75\end{array}$ & $9 \cdot 01(4 \cdot 68)$ & $\begin{array}{r}-0.41 \\
0.54 \\
1.25 \\
1.07\end{array}$ & $\begin{array}{r}-0.25 \\
0 \cdot 18 \\
0.93 \\
0.77\end{array}$ & $\begin{array}{r}-0.27 \\
0.28 \\
0.89 \\
1.03\end{array}$ \\
\hline $\begin{array}{l}\text { p Value for: } \\
\text { Effect of smoking } \\
\text { Linear trend } \\
\text { Quadratic trend }\end{array}$ & & & $\begin{array}{l}<0.001 \\
>0.05\end{array}$ & $\begin{array}{c}<0.001 \\
0.01 \\
>0.05\end{array}$ & $\begin{array}{l}<0 \cdot 001 \\
<0 \cdot 001 \\
>0 \cdot 05\end{array}$ \\
\hline \multicolumn{6}{|c|}{ Women } \\
\hline $\begin{array}{l}\text { No of cigarettes smoked } \\
\text { None } \\
1-9 \\
10-19 \\
\geqslant 20\end{array}$ & $\begin{array}{l}2832^{4179} \\
758 \\
510 \\
79\end{array}$ & $9 \cdot 73(4 \cdot 62)$ & $\begin{array}{r}-0.54 \\
0.89 \\
1.43 \\
1.63\end{array}$ & $\begin{array}{r}-0.35 \\
0.55 \\
0.98 \\
1.09\end{array}$ & $\begin{array}{r}-0.39 \\
0.64 \\
0.95 \\
1.06\end{array}$ \\
\hline $\begin{array}{l}\text { p Value for: } \\
\text { Effect of smoking } \\
\text { Linear trend } \\
\text { Quadratic trend }\end{array}$ & & & $\begin{array}{r}<0.001 \\
0.005\end{array}$ & $\begin{array}{l}<0.001 \\
<0.001 \\
>0.05\end{array}$ & $\begin{array}{l}<0.001 \\
<0.001 \\
>0.05\end{array}$ \\
\hline
\end{tabular}

and having five or more such passes (but no higher qualification). The relations were generally stronger than those found for height and remained highly significant after allowing for the other independent variables. As might be expected, birth weight had less effect in the association between smoking in pregnancy and educational qualifications than in the analysis of height. The difference between the two sets of adjusted deviations was slight and mainly due to the rather strange results for the sons of the heaviest smokers, a fairly small group. In general, the offspring of both sexes showed only a small difference in educational qualifications between the two groups whose mothers had smoked $10-19$ or 20 or more cigarettes a day during pregnancy but a steady gradient in educational attainment to the lower categories of smoking in pregnancy.

\section{Discussion}

As predicted from the results when the cohort was aged $16^{9}$ our analyses provide little support for a relation continuing into adulthood between physical growth and smoking in pregnancy when social class, size of family, birth weight for gestational age, and mother's height are taken into account. This finding contrasts with those in early childhood, although our analyses were designed to be comparable with those used before. One difference that must be considered is in the measurement of height. At the follow ups at 7 , 11 , and 16 height was measured during medical examinations whereas at 23 it was self reported. Self reported measurements are probably less accurate, but self reported height is sufficiently valid for epidemiological analysis. ${ }^{18}{ }^{19}$ Furthermore, the data on height from the national child development study have been checked and amended for inconsistencies and improbable values. ${ }^{20}$

Our findings may imply that a causal relation does not exist between smoking in pregnancy and growth, but with the results obtained at earlier ages they seem more compatible with the suggestion that smoking in pregnancy either affects the rate of growth but not total growth or affects growth until puberty, when the greater changes then occurring obscure its effect. This conclusion is, however, limited to the question of whether smoking in pregnancy affects height, which is additional to its association with birth weight. The question of whether the eventual height differs once social background and the mother's own height have been allowed for is more strongly supported, particularly for women. The possible initial impact of smoking in pregnancy on the development of the child; as indicated by its birth weight, does not seem to have evaporated by adulthood, as indicated by height.

The relation of smoking in pregnancy with the educational achievements of the offspring as measured by the highest qualification obtained by age 23 remained strong, even after allowing for social class, size of family, birth weight for gestational age, and mother's height, and was not substantially affected by the omission of birth weight from the analyses. The differences in achievement associated with smoking, although difficult to interpret precisely, clearly represent a distinguishable shift in the level of qualification. Such differences are certainly significant when fine decisions are being made about job selection or entering further or higher education. The persistence of a difference was expected as the test scores in reading and mathematics were different at earlier ages, and these may be expected to predict subsequent qualifications. That the relation is so strong and of such potential practical importance is, however, surprising. As far as can be judged the relation at age 23 may be rather stronger than at 16 . The differences in the test 
scores in reading and mathematics between the extreme categories of smoking represented 0.12 and 0.18 of the standard deviation of the population. The equivalent figures for the scale of qualifications at age 23 are $\mathbf{0 . 2 2}$ for men and $\mathbf{0 . 3 1}$ for women (which is not explained by including the additional category of smoking in this analysis).

Of course these are observational data and an unequivocal indication of a causal relation cannot be claimed. The analysis did not include, for example, a measure of the mother's intellectual development, which might be expected to be related both to her smoking habits (but perhaps less so in 1958 than now) and to the achievements of her child. Nevertheless, the evidence seems strong enough to justify warnings against smoking in pregnancy because of the possible implications for the long term physical and intellectual development of the child, in addition to the other dangers.

We thank our colleagues for their helpful comments, in particular Dr C Power, Professor A J Fox, and Mr P Shepherd. This work is supported by City University.

1 Davie R, Butler NR, Goldstein H. From birth to seven. London: Longman, 1972.

2 Fogelman K, ed. Growing up in Great Britain. London: Macmillan, 1983.

3 Butler NR, Golding J, eds. From birth to five. London: Pergamon, 1986.

4 Butler NR, Alberman ED. Perinatal problems. Edinburgh: E and S Livingstone, 1969.
5 Butler NR, Goldstein H, Ross EM. Cigarette smoking in pregnancy: its influence on birth weight and perinatal mortality. Br Med f 1972;ii:127-30. Peters T, Golding, J, Lawrence CJ, Fryer JG, Chamberlain GVP, Butler NR. Plus ça change: a comparative analysis of predictors of birthweight. $B r \mathcal{F}$ Obstet Gynaecol 1983:90:1040-5.

7 Goldstein H. Factors influencing the height of seven-year-old children. Hum Biol 1971;43:92-111.

8 Butler NR, Goldstein H. Smoking in pregnancy and subsequent child development. Br Med F 1973;iv:573-5.

9 Fogelman K. Smoking in pregnancy and subsequent development of the child. Child: Care, Health and Development 1980;6:233-49.

10 Butler NR, Bonham DG. Perinatal mortality. Edinburgh: E and S Livingstone, 1963.

11 National Child Development Study Research Team. The fourth follow-up of the National Child Development Study. London: City University, 1987. (National Child Development Study User Support Group working pape No 20.)

12 Fox AJ, Fogelman K. New possibilities for longitudinal studies of intergenerational factors in child health and development. London: City University, 1988. (National Child Development Study User Support Group working paper No 26.

13 Fogelman K. After school: the education and training experiences of the 1958 cohort. London: Further Education Unit, 1985.

14 Goldstein $\mathrm{H}$. A study of response rates of 16 -year-olds in the national child development study. In: Fogelman K, ed. Growing up in Great Britain. development study. In: Fogel

15 Iyer R. Analysis of response. London: City University, 1984. (NCDS4 working paper No 25.)

16 Winer BJ. Statistical principles in experimental design. London: McGraw Hill, 1975.

17 Gaito J. Introduction to analysis of variance procedures. New York: MSS Information Corporation, 1973 .

18 Palta M, Prineas RJ, Berman R, Hannan P. Comparison of self reported an measured height and weight. Am $\mathcal{F}$ Epidemiol 1982;115:223-30.

19 Schlichting P, Hoilund-Carlson PF, Quaade F. Comparison of self reported height and weight with controlled height and weight in women and men. Int $\mathcal{F}$ Obes 1981;5:67-76.

20 Power C, Moynihan C. Social class and changes in weight-for-height between childhood and early adulthood. Int $\mathcal{f}$ Obes. (in press).

(Accepted 10 August 1988)
Diabetes Research Unit, Department of Medicine, University of Wales College of Medicine, Heath Park, Cardiff CF4 4XN Jiten P Vora, MRCP, senior registrar

David R Owens, MD, senior lecturer

John Dolben, MRCP, research fellow

Jameel A Atiea, MRCP, research fellow

John D Dean, MRCP, research fellow

Steven Kang, MRCP, research fellow

\section{Department of Medical} Physics, University of Wales College of Medicine, Heath Park, Cardiff CF4 4XN

Anna Burch, MA, senior physicist

Novo Research Institute, DK-2880 Bagsvaerd,

Denmark

Jens Brange, MSC PHARM, research manager

Correspondence to: Dr Owens.

\title{
Recombinant DNA derived monomeric insulin analogue: comparison with soluble human insulin in normal subjects
}

\author{
Jiten P Vora, David R Owens, John Dolben, Jameel A Atiea, John D Dean, Steven Kang, \\ Anna Burch, Jens Brange
}

\section{Abstract}

Objective-To compare the rate of absorption from subcutaneous tissue and the resulting hypoglycaemic effect of iodine-125 labelled soluble human insulin and a monomeric insulin analogue derived by recombinant DNA technology.

Design-Single blind randomised comparison of equimolar doses of ${ }^{125}$ I labelled soluble human insulin and insulin analogue.

Setting-Study in normal people at a diabetes research unit and a university department of medical physics.

Subjects-Seven healthy male volunteers aged 2039 not receiving any other drugs.

Interventions - After an overnight fast and a basal period of one hour two doses $(0.05$ and $0.1 \mathrm{U} / \mathrm{kg})$ of ${ }_{125}$ I labelled soluble human insulin and insulin analogue were injected subcutaneously into the anterior abdominal wall on four separate days.

End point-To find a fast acting insulin for meal related requirements in insulin dependent diabetics.

Measurements and main results-Residual radioactivity at the injection site was measured continuously for the first two hours after injection of the ${ }^{125}$ I labelled preparations and thereafter for five minutes simultaneously with blood sampling. Frequent venous blood samples were obtained over six hours for determination of plasma immunoreactive insulin, insulin analogue, glucose, and glucagon values. Time to $50 \%$ of initial radioactivity at the injection site for the insulin analogue compared with soluble insulin was $61 v 135$ minutes $(\mathrm{p}<0.05)$ with $0.05 \mathrm{U} / \mathrm{kg}$ and $67 v 145$ minutes $(\mathrm{p}<0.001)$ with 0.1
U/kg. Concentrations in plasma increased faster after the insulin analogue compared with soluble insulin, resulting in higher plasma concentrations between 10 and 150 minutes $(0.001<p<0.05)$ after $0.05 \mathrm{U} / \mathrm{kg}$ and between 40 and 360 minutes $(0.001<\mathrm{p}<0.05)$ after $0.1 \mathrm{U} / \mathrm{kg}$. The hypoglycaemic response to insulin analogue was a plasma glucose nadir at 60 minutes with both doses compared with 90 and 120 minutes with soluble insulin at 0.5 and 0.1 $\mathrm{U} / \mathrm{kg}$ respectively. The response of glucagon substantiated the earlier and more dramatic hypoglycaemic effect with the insulin analogue.

Conclusions-The much faster absorption from subcutaneous tissue of the disubstituted monomeric insulin analogue compared with soluble insulin suggests that the analogue may be a potential candidate for rapid insulin delivery after subcutaneous bolus injection.

\section{Introduction}

In normal people physiological endogenous insulin secretion is related to the availability of substrate and the prevailing glycaemic value..$^{14}$ Eating a meal results in a rapid rise in plasma insulin concentration, reaching a peak within $30-60$ minutes. ${ }^{356}$ By contrast, the subcutaneous injection of soluble insulin produces peak plasma concentrations at 90-120 minutes, ${ }^{7-9}$ necessitating injection around 30 minutes before a meal in an attempt to minimise postprandial hyperglycaemia. ${ }^{1011}$

The initial delay in the absorption of commercially available soluble insulin from the subcutaneous tissue has been attributed to the rate of dissociation from 